\title{
Transfer of monoterpenes and sesquiterpenes from forages into milk fat
}

\author{
Christine VIALlON ${ }^{\mathrm{a}}$, Bruno MARTIN ${ }^{\mathrm{b}}$, Isabelle VERDIER-MetZ ${ }^{\mathrm{c}}$, \\ Philippe Pradel ${ }^{\mathrm{d}}$, Jean-Paul GAREL ${ }^{\mathrm{d}}$, Jean-Baptiste COUlON ${ }^{\mathrm{b}}$, \\ Jean-Louis BERDAGUÉ ${ }^{a *}$ \\ ${ }^{a}$ Laboratoire Flaveur, INRA Clermont-Ferrand-Theix, 63122 Saint-Genès-Champanelle, France \\ ${ }^{\mathrm{b}}$ Unité de Recherches sur les Herbivores, INRA Clermont-Ferrand-Theix, \\ 63122 Saint-Genès-Champanelle, France \\ ${ }^{\mathrm{c}}$ Laboratoire de Recherches Fromagères, INRA, 15000 Aurillac, France \\ ${ }^{\mathrm{d}}$ Domaine de la Borie, INRA, 15330 Marcenat, France
}

(Received 23 February 2000; accepted 8 June 2000)

\begin{abstract}
The transfer of monoterpenes and sesquiterpenes from forages into milk fat was studied in a group of cows fed successively with forages containing high and low amounts of these substances. In a first 24-d period the cows received $11 \mathrm{~kg}$ of a cocksfoot hay containing low quantities of monoterpenes and sesquiterpenes. In a second 36- $\mathrm{d}$ period, $3 \mathrm{~kg}$ of the cocksfoot were replaced by $3 \mathrm{~kg}$ of yarrow, a plant rich in terpenoids. In a third 24-d period the cows returned to the cocksfootbased diet they were fed in the first period. The quantities of monoterpenes and sesquiterpenes desorbed from the milk fat were measured by dynamic headspace - gas chromatography - mass spectrometry. Results showed that the quantities of monoterpenes had increased by the first milking carried out $8 \mathrm{~h}$ after ingestion of yarrow, whereas the increase in the quantities of sesquiterpenes was observed only after the third milking, $32 \mathrm{~h}$ after the diet change. The maximal quantities of monoterpenes and sesquiterpenes were measured after $4 \mathrm{~d}$ of the yarrow-enriched diet, after which the total quantities decreased, despite the constant supply of yarrow. Four days after discontinuing yarrow the amounts of monoterpenes and sesquiterpenes desorbed from the milk fat reverted to those measured during the first period.
\end{abstract}

traceability / type of feeding / terpenoid analysis / purge-and-trap / gas chromatography-mass spectrometry

Résumé - Transfert des monoterpènes et des sesquiterpènes des fourrages dans la matière grasse du lait. Le transfert des monoterpènes et des sesquiterpènes des fourrages dans la matière grasse du lait a été étudié sur un lot de vaches successivement nourries avec des fourrages riches ou pauvres

* Correspondence and reprints

Tel.: (33) 4736241 91; fax: (33) 4736247 31; e-mail: Berdague @ clermont.inra.fr 
en ces composés. Au cours d'une première période de $24 \mathrm{j}$, les animaux ont reçu $11 \mathrm{~kg}$ d'un foin de dactyle pauvre en monoterpènes et sesquiterpènes. Au cours d'une seconde période de $36 \mathrm{j}, 3 \mathrm{~kg}$ de dactyle ont été remplacés par $3 \mathrm{~kg}$ de foin d'achillée millefeuille riche en terpénoïdes. Durant une troisième période de $24 \mathrm{j}$, les animaux ont à nouveau reçu le régime à base de foin de dactyle de la première période. Le dosage des quantités de monoterpènes et de sesquiterpènes désorbées par la matière grasse du lait a été réalisé par espace de tête dynamique - chromatographie en phase gazeuse - spectrométrie de masse. Les analyses ont montré que les quantités de monoterpènes ont augmenté dès la première traite effectuée $8 \mathrm{~h}$ après l'ingestion de l'achillée tandis que l'augmentation des quantités de sesquiterpènes était observée à partir de la troisième traite soit $32 \mathrm{~h}$ après le changement de régime. Les quantités maximales de monoterpènes et sesquiterpènes ont été détectées après $4 \mathrm{j}$ de régime supplémenté en achillée puis - malgré l'apport constant de ce fourrage - une diminution des quantités totales a été observée. Quatre jours après la suppression de l'achillée, les quantités de monoterpènes et sesquiterpènes désorbées par la matière grasse du lait ont été identiques à celles mesurées en première période.

traçabilité / type d'alimentation / analyse des terpénoïdes / purge-and-trap / chromatographie en phase gazeuse-spectrométrie de masse

\section{INTRODUCTION}

The impact of animal feeding on the monoterpene and sesquiterpene contents of cheese has been studied by many authors. Dumont and Adda [6] and later Dumont et al. [7], Bosset et al. [1, 2], and Buchin et al. [3] have shown that these odoriferous compounds typical of the plant kingdom occur in greater amounts in dairy products when the cows are fed mountain forages. High-altitude forages display a larger botanical diversity and contain many terpenoid-rich dicotyledons. In a more recent work Viallon et al. [18] showed that these substances can also help to characterise products made from milk obtained from cows fed forages with different compositions and from different geographical areas. The aim of this work is to study the evolution of the quantities of monoterpenes and sesquiterpenes extracted from milk fat resulting from temporary diets of forages containing high and low amounts of these substances. For this purpose, a new method for the analysis of terpenoid compounds was developed. This study should underline the interest in considering the monoterpenes and sesquiterpenes as tracers of the feeding of animals and (or) the geographical origin of dairy products.

\section{MATERIALS AND METHODS}

\subsection{Experimental conditions}

Three Tarantaise cows producing on average $9.8 \mathrm{~kg}$ of milk per day were successively fed three diets. During the first period P1, lasting $24 \mathrm{~d}$, the cows were given a diet of $11 \mathrm{~kg}$ of cocksfoot hay (Dactylis glomerata), low in monoterpenes and sesquiterpenes, like most monocotyledons $[14,18]$. This hay came from a plot located at an altitude of $1000 \mathrm{~m}$ at the INRA research station at Marcenat (Cantal, France). It was a second-cut forage harvested in September and dried on the ground. The hay ration, dispensed in two daily meals, was supplemented with $2 \mathrm{~kg}$ of barley and $0.3 \mathrm{~kg}$ of soya-bean meal. During the second period P2, lasting $36 \mathrm{~d}, 3 \mathrm{~kg}$ of cocksfoot hay was replaced by $3 \mathrm{~kg}$ of dried yarrow (Achillea millefolium), a terpene-rich specie $[10,13]$ commonly found in natural pastures, and readily grazed by cows. The yarrow was incorporated into the ration as 2 to $3 \mathrm{~cm}$ long blades mixed with the barley and the soya-bean meal. The plants were purchased in dried form from a supplier specialised in the sale of aromatic and medicinal plants (SICA RAPAM, Aubiat, France). 
They comprised inflorescences harvested at flowering time at different locations in the Puy-de-Dôme and Haute-Loire areas of the Massif Central (central France). During the third period P3, the cows were fed once more with the same diet as in period $\mathrm{P} 1$ for $24 \mathrm{~d}$. All the diet changes were made starting with the morning meal.

\subsection{Milk sampling}

Milk was sampled during all three periods at the evening milking session before the evening meal. Each sample was a mixture of milk from all three cows. In period P1, samples were taken on days D1, D7, D14 and D21. In period P2 they were taken on days D1 (i.e. $8 \mathrm{~h}$ after the diet change), D2 (32 h), D4, D6, D11, D18, D26 and D32. In period P3 they were taken on D1 $(8 \mathrm{~h})$, D2 (32 h), D4, D6, D10, D16 and D24.

\subsection{Fat preparation}

The milk was skimmed immediately after milking. In all, nineteen $50 \mathrm{~mL}$ samples of cream were prepared and stored at $-20{ }^{\circ} \mathrm{C}$. The fat was extracted after thawing for one night at ambient temperature, after which $20 \mathrm{~g}$ of cream were weighed and loaded into ultracentrifuge tubes. The fat phases were obtained after spinning for $1 \mathrm{~h}$ at $100000 \mathrm{~g}$ at $12{ }^{\circ} \mathrm{C}$ in a Beckman L90 ultracentrifuge (93220 Gagny, France). Aliquots of $5 \mathrm{~mL}$ of supernatant liquid fat phase (clear yellow) were pipetted off with a Pasteur pipette, sealed and stored at $-20^{\circ} \mathrm{C}$ in $10 \mathrm{~mL}$ glass vials (nb. 5182-0837, Hewlett Packard, 91947 Les Ulis, France) until the analyses of mono- and sesquiterpenes.

\subsection{Analysis of monoterpenes and sesquiterpenes}

The analysis of monoterpenes and sesquiterpenes was conducted on the nineteen fat phase samples and on the two forages.

\subsubsection{Extraction}

The monoterpenes and sesquiterpenes were extracted by the dynamic head space method using a Tekmar LSC 2000 apparatus (Cincinnati, OH 45234, USA). A sample of $0.1 \mathrm{~g}$ of forage or $0.2 \mathrm{~g}$ of fat phase was placed in a glass extraction cartridge (diameter $28 \mathrm{~mm}$, height $70 \mathrm{~mm}$ ). The extraction conditions were: purge gas helium, purge flow rate $65 \mathrm{~mL} \cdot \mathrm{min}^{-1}$, purge time and temperature of $30 \mathrm{~min}$ at $110^{\circ} \mathrm{C}$, dry purge 0 , type of trap Tekmar Tenax, cool-down temperature $-150{ }^{\circ} \mathrm{C}$, desorb preheat temperature $175^{\circ} \mathrm{C}$, desorb time $5 \mathrm{~min}$ at $180{ }^{\circ} \mathrm{C}$, inject time $2 \mathrm{~min}$ at $225^{\circ} \mathrm{C}$ in a chromatograph set at $35^{\circ} \mathrm{C}$, bake time $10 \mathrm{~min}$ at $180^{\circ} \mathrm{C}$.

\subsubsection{Separation}

The compounds were separated by gas chromatography using a Hewlett Packard 5890 chromatograph. The separation conditions were: capillary column $(60 \mathrm{~m} \times$ $0.32 \mathrm{~mm}$ ) (Supelco, 1196 Gland, Switzerland), stationary phase, SPB5 (1 $\mu \mathrm{m})$, carrier gas helium $\left(1 \mathrm{~mL} \cdot \mathrm{min}^{-1}\right)$, oven program $5 \mathrm{~min}$ at $35^{\circ} \mathrm{C}$, rise to $230{ }^{\circ} \mathrm{C}$ at $3{ }^{\circ} \mathrm{C} \cdot \mathrm{min}^{-1}$ then plateau $2 \mathrm{~min}$ at $230{ }^{\circ} \mathrm{C}$.

\subsubsection{Detection and quantification}

The terpenoids were detected by electronic impact mass spectrometry using a Hewlett Packard 5971S spectrometer. To increase the specificity and sensitivity of the detection only masses 93, 136 (monoterpenes) and 93, 136, 161, 204 (sesquiterpenes) were recorded. The respective sums of these four masses were integrated for each chromatogram using MS Chemstation software (Hewlett Packard, 91947 Les Ulis, France), to estimate the overall desorptions of the two families of compounds during the three experimental periods. 


\section{RESULTS AND DISCUSSION}

The measurements showed that the evolution of the quantities of monoterpenes and sesquiterpenes desorbed from the milk fat was very similar (Fig. 1). These quantities cannot be compared because the integration of the chromatographic profiles was performed on the sum of specific ions and not on the total ion count.

The analyses conducted during period $\mathrm{P} 1$ and at the beginning of period P2 showed that ingestion of yarrow resulted in a gradual increase in the quantities of monoterpenes and sesquiterpenes in the milk fat, and that their desorption was maximal about $4 \mathrm{~d}$ after the change of diet (Fig. 1). This gradual increase is due to the time required for the terpenoids to diffuse through the various tissues to the mammary gland. This transit can take place via various routes including the digestive tract. In this case the

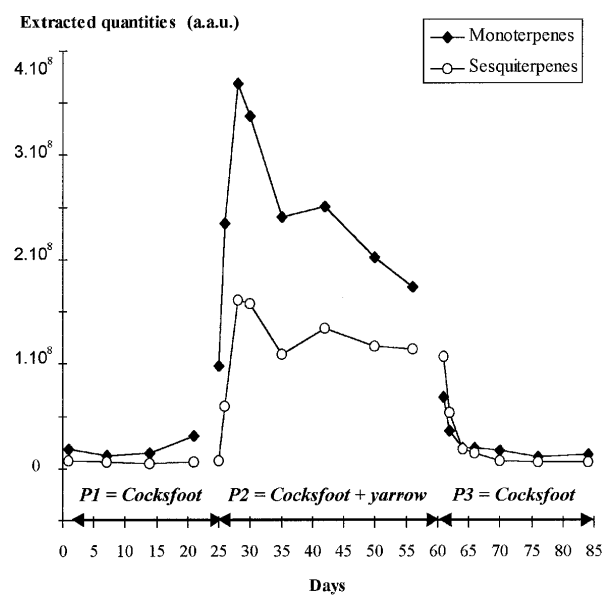

Figure 1. Quantities of monoterpenes and sesquiterpenes extracted from milk fat during different diet periods.

The quantities are expressed in arbitrary area units (a.a.u.).

Figure 1. Quantités de monoterpènes et de sesquiterpènes extraites de la matière grasse du lait en fonction des différentes périodes de régime. Les quantités sont exprimées en unités arbitraires de surface (u.a.s.). monoterpenes and sesquiterpenes ingested by the cows are absorbed in the digestive tract, i.e. rumen and (or) intestine, before diffusing into the blood compartment and reaching peripheral tissues such as the mammary gland. A second possible absorption route is the pulmonary route. In this case terpenoids present in the yarrow diffuse in the air and are inhaled by the cows. They are absorbed in the lungs, enter the blood stream, and diffuse to the mammary gland. The existence of this second transfer route was demonstrated by Dougherty et al. [5] and Shipe et al. [17] in works on animals equipped with tracheal and ruminal cannulae. They showed that this absorption route was the faster one. Thus, when the cows inhaled aromatic substances off-flavors were detected in the milk 15 min after the start of the experiment. However, $30 \mathrm{~min}$ to $1 \mathrm{~h}$ was necessary to detect milk off-flavors when aromatic substances were introduced into the rumen. These authors also showed that this time of $30 \mathrm{~min}$ to $1 \mathrm{~h}$ could be shortened if gases eructated by the cows were allowed to enter their lungs. Other authors focused on the transfer of odoriferous substances into milk. Honkanen et al. [11] reported that according to the substances tested, the peak concentrations in the milk generally occurred 2 to $4 \mathrm{~h}$ after introduction of the substances into the rumen. This value of 2 to $4 \mathrm{~h}$ is very far from that of about $4 \mathrm{~d}$ found by us. This difference is probably due to the chemical nature of the compounds studied. Honkanen et al. [11] worked mostly with polar compounds (alcohols, aldehydes, ketones and esters) that diffuse readily in the blood compartment. In contrast, monoterpenes and sesquiterpenes are apolar compounds that probably diffuse more slowly in the blood and like fatty acids may need carriers.

Analyses conducted during period P2 after $4 \mathrm{~d}$ showed that the desorption of monoterpenes and sesquiterpenes decreased even though the supply of yarrow was constant (Fig. 1). Two explanations can be suggested for this decrease. First it may be due 


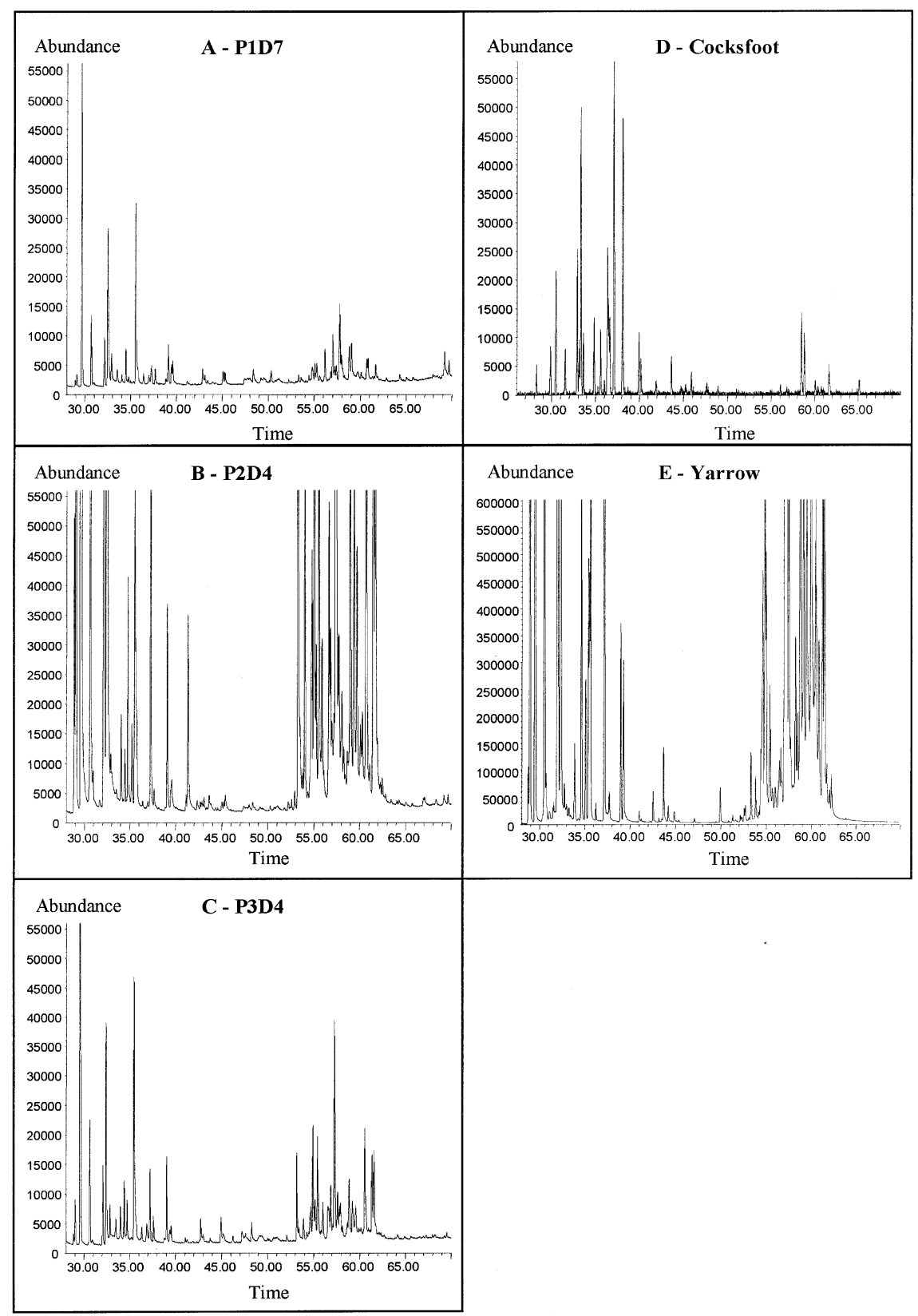

Figure 2. Chromatographic profiles obtained for milk fat (ABC) and forages (DE).

A, Cocksfoot diet: period 1 - day 7; B, Cocksfoot + yarrow diet: period 2 - day 4; C, Cocksfoot diet: period 3 - day 4; D, Cocksfoot forage; E, Yarrow forage.

Figure 2. Profils chromatographiques obtenus sur la matière grasse du lait (ABC) et les fourrages (DE). A, régime dactyle : période 1 - jour $7 ; B$, régime dactyle + achillée millefeuille : période 2 - jour 4 ; $\mathrm{C}$, régime dactyle : période 3 - jour $4 ; \mathrm{D}$, foin de dactyle ; E, foin d'achillée millefeuille. 
to the microbial flora of the rumen, which after a period of adaptation to the change in diet begins to degrade these compounds totally or partially. Several literature studies indicate that certain micro-organisms can break down terpenes, although the species and physico-chemical conditions studied are not always those met in the rumen $[9,12,15]$. Secondly, it may be that the observed decrease occurs because the terpenoids are directed preferentially towards other tissues or simply eliminated by the animals. Clearance and detoxification by hepatic [8] or urinary routes $[4,16]$ may occur when the concentrations in the animal become too high.

Analyses conducted during period P3 showed that the return to a cocksfoot-based diet caused a decrease in the quantities of the 2 classes of terpenoids, but it is not before $\mathrm{D} 4$ that the values measured revert to the levels of period P1 (Fig. 1). This decrease is due to the gradual elimination of the compounds from each of the various tissues.

A more detailed study of the evolution of the terpenoid quantities during the diet changes revealed a gap between the monoterpenes and the sesquiterpenes (Fig. 1). Variations in the quantities of monoterpenes appeared in periods $\mathrm{P} 2$ or P3, i.e. $8 \mathrm{~h}$ after diet change, whereas variations in the quantities of sesquiterpenes were observed in samples taken $2 \mathrm{~d}$, i.e. $32 \mathrm{~h}$ after the start of the second or third periods (Fig. 1). The real significance of this gap is difficult to interpret owing to the low number of samplings. It is probably due to differences in solubility in the two tissues of the two categories of terpenoids, linked to their molecular weights.

The chromatographic profiles corresponding to the analyses carried out on P1D7, P2D4 and P3D4 show the differences in composition of the milk fat according to the three diet periods (Figs. 2A, 2B, 2C). The comparison of these chromatograms with those of the forages (Figs. 2D, 2E) clearly show that the monoterpenes and the sesquiterpenes detected in milk fat come from the two forages. All the chromatographic profiles confirm the sensitivity of the method used. In our experimental conditions, it was possible to detect easily and with an excellent signal-to-noise ratio more than 20 monoterpenes and more than 30 sesquiterpenes in the milk fat samples (Fig. 2B).

\section{CONCLUSION}

This work clearly shows that a modification of the plant species composition of forages strongly influences the proportions and quantities of monoterpenes and sesquiterpenes in milk fat. In addition, the transfer of these compounds into milk fat is very fast and apparently exhibits no memory effect. Hence, their analysis seems to be interesting in order to acquire a chemical fingerprint of the recent feeding of the animals.

\section{ACKNOWLEDGMENTS}

The authors thank E. Albaret and his staff for the sampling and cream preparation and the "Commissariat à l'aménagement et au développement économique du Massif Central" for supporting the study.

\section{REFERENCES}

[1] Bosset J.O., Bütikofer U., Gauch R., Sieber R., Caractérisation de fromages d'alpages subalpins suisses : mise en évidence par GC-MS de terpènes et d'hydrocarbures aliphatiques lors de l'analyse par "Purge and Trap" des arômes volatils de ces fromages, Schweiz. Milchw. Forsch. 23 (1994) 37-41.

[2] Bosset J.O., Jeangros B., Berger T., Bütikofer U., Collomb M., Gauch R., Lavanchy P., Scehovic J., Troxler J., Sieber R., Comparaison de fromages à pâte dure de type Gruyère produits en régions de montagne et de plaine, Rev. Suisse Agric. 31 (1999) 17-22.

[3] Buchin S., Delague V., Duboz G., Berdagué J.L., Beuvier E., Pochet S., Grappin R., Influence of pasteurization and fat composition of milk 
on the volatile compounds and flavor characteristics of a semi-hard cheese, J. Dairy Sci. 81 (1998) 3097-3108.

[4] Crowell P.L., Prevention and therapy of cancer by dietary monoterpenes, Amer. Soc. Nutr. Sci. (1999) 775S-778S

[5] Dougherty R.W., Shipe W.F., Gudnason G.V., Ledford R.A., Peterson R.D., Scarpellino R., Physiological mechanisms involved in transmitting flavours and odors to milk. I. Contribution of eructated gases to milk flavor, J. Dairy Sci. 45 (1962) 472-476.

[6] Dumont J.P., Adda J., Occurrence of sesquiterpenes in mountain cheese volatiles, J. Agric. Food Chem. 26 (1978) 364-367.

[7] Dumont J.P., Adda J., Rousseaux P., Exemple de variation de l'arôme à l'intérieur d'un même type de fromage : le Comté, Lebensm. Wiss. Technol. 14 (1981) 198-202.

[8] Egorin M.J., Sentz D.L., Rosen D.M., Ballesteros M.F., Kearns C.M., Callery P.S., Eiseman J.L., Plasma pharmacokinetics, bioavailability, and tissue distribution in $\mathrm{CD} 2 \mathrm{~F} 1$ mice of halomon, an antitumor halogenated monoterpene isolated from the red algae Portieria hornemannii, Cancer Chemother. Pharmacol. 39 (1996) 51-60.

[9] Fagan G.L., Kepner R.E., Webb A.D., Production of linalool, cis- and trans-nerolidol and trans-farnesol by Saccharomyces fermentati growing on a film of simulated wine, Vitis 20 (1981) 36.

[10] Figueiredo A.C., Barroso J.G., Pais M.S.S., Scheffer J.J.C., Composition of the essential oils from leaves and flowers of Achillea millefolium L. ssp. Millefolium, Flavour Fragr. J. 7 (1992) 219-222.

[11] Honkanen E., Karvonen P., Virtanen A.I., Studies on the transfer of some flavour compounds to milk, Acta Chem. Scand. 18 (1964) 612-618.

[12] Hylemon P.B., Harder J., Biotransformation of monoterpenes, bile acids, and other isoprenoids in anaerobic ecosystems, FEMS Microbiol. Rev. 22 (1999) 475-488.

[13] Lawrence B.M., Progress in Essential Oils, Perfum. Flavor. 22 (1997) 57-74.

[14] Mariaca R.G., Berger T.F.H., Gauch R., Imhof M.I., Jeangros B., Bosset J.O., Occurrence of volatile mono- and sesquiterpenoids in highland and lowland plant species as possible precursors for flavor compounds in milk and dairy products, J. Agric. Food Chem. 45 (1997) 4423-4434.

[15] Misra G., Pavlostathis S.G., Perdue E.M., Araujo R., Aerobic biodegradation of selected monoterpenes, Appl. Microbiol. Biotechnol. 45 (1996) 831-838.

[16] Miyazawa M., Kameoka H., Morinaga K. Negoro K., Mura N., Hydroxycineole: four new metabolites of 1,8-cineole in rabbits, J. Agric Food Chem. 37 (1989) 222-226.

[17] Shipe W.F., Ledford R.A., Peterson, R.D., Scanlan R.A., Geerken H.F., Dougherty R.W., Morgan M.E., Physiological mechanisms involved in transmitting flavors and odors to milk. II. Transmission of some flavor components of silage, J. Dairy Sci. (1962) 477-480.

[18] Viallon C., Verdiez-Metz I., Denoyer C., Pradel P., Coulon J.-B., Berdagué J.-L., Desorbed terpenes and sesquiterpenes from forages and cheeses, J. Dairy Res. 66 (1999) 319-326. 